\title{
RASIONALITAS PENGGUNAAN OBAT ANTIHIPERTENSI PADA PASIEN HIPERTENSI RAWAT INAP DI RS DAERAH Dr. A. DADI TJOKRODIPO BANDAR LAMPUNG
}

\section{THE RATIONALITY OF ANTI-HYPERTENSION MEDICINE ON HYPERTENSION INPATIENTS AT PUBLIC HOSPITAL OF Dr. A. DADI TJOKRODIPO BANDAR LAMPUNG}

\author{
Mashuri Yusuf ${ }^{1}$, Subur Widodo ${ }^{2}$, Diah Pitaloka ${ }^{3}$ \\ Fakultas MIPA, Program Studi Farmasi Universitas Tulang Bawang Lampung \\ Email : mashuriyusuf09@gmail.com \\ HP. 0812-7379-2722
}

\begin{abstract}
Hypertension is one of non contagious diseases marked by the increase of systolic blood pressure $>140 \mathrm{mmHg}$ and diastolic blood pressure $>90 \mathrm{mmHg}$. Hypertension becomes the main risk factor of other cardiovascular diseases. The number of hypertension occurance with or without companion increases every year. The purpose of this research is to know the rationality of antihypertension medicine usage on hypertension inpatients at RSUD of Dr. A. Dadi Tjokrodipo Bandar Lampung year of 2019 based on precise patient, precise indication, precise medicine, and precise dosage using reference standard of Guidelines JNCVIII. This research was a descriptive research with data collection of medical record retrospectively. The technique of sample selection used purposive sampling technique. The research results obtained from 82 samples based on the patients' characteristics of genders such as 50 female patients $(60,98 \%)$ and 42 male patients $(39,02 \%)$. The patients' characteristics based on age obtain mostly the patients are at age of 46-55 years old in the amount of 39 patients (47,6\%). The patients' characteristics based on the pattern of medicine usage obtain the most anti-hypertension used is amlodipin CCB class in the amount of 54 patients (45\%). Rationality evaluation of anti-hypertension medicine usage obtains precise patient in the amount of 81 patients $(99,8 \%)$, precise indication in the amount of 82 patients $(100 \%)$, precise medicine in the amount of 61 patients $(74,4 \%)$, and precise dosage in the amount of 82 patients (100\%). The conclusion of this research is the usage of hypertension on the hypertension inpatients at Public Hospital of Dr. A. Dadi Tjokrodipo Bandar Lampung is already rational.
\end{abstract}

Keywords: Anti-hypertension, Hypertension, Rationality of Medicine Usage 


\begin{abstract}
Abstrak
Hipertensi merupakan salah satu penyakit tidak menular yang ditandai dengan peningkatan tekanan darah sistolik $>140 \mathrm{mmHg}$ dan tekanan darah diastolik $>90$ $\mathrm{mmHg}$. Hipertensi menjadi faktor risiko utama penyakit kardiovaskuler lainnya. Angka kejadian hipertensi dengan atau tanpa penyerta meningkat tiap tahunnya, sehingga potensi adanya ketidakrasionalan penggunaan obat semakin meningkat. Tujuan dari penelitian ini untuk mengetahui rasionalitas penggunaan obat antihipertensi paa pasien hipertensi rawat inap di RSUD Dr. A. Dadi Tjokrodipo Bandar lampung tahun 2019 berdasarkan tepat pasien, tepat indikasi, tepat obat, dan tepat dosis menggunakan standar acuan Guidelines JNCVIII. Penelitian ini secara deskriptif dengan pengambilan data rekam medik secara retrospektif.Teknik pengambilan sampel menggunakan teknik purposive sampling. Hasil penelitian yang diperoleh dari 82 sampel berdasarkan karakteristik pasien untuk jenis kelamin yaitu 50 pasien perempuan $(60,98 \%)$ dan 42 pasien laki-laki $(39,02 \%)$. Karakteristik pasien berdasarkan usia diperoleh paling banyak pada usia 46-55 tahun sebanyak 39 pasien $(47,6 \%)$.Karakteritik pasien berdasarkan pola penggunaan obat diperoleh antihipertensi yang paling banyak digunakan yaitu amlodipin golongan CCB sebanyak 54 pasien (45\%). Evaluasi rasionalitas penggunaan obat antihipertensi diperoleh yaitu tepat pasien sebanyak 81 pasien $(99,8 \%)$, tepat indikasi sebanyak 82 pasien (100\%), tepat obat sebanyak 61 pasien $(74,4 \%)$, dan tepat dosis sebanyak 82 pasien (100\%).Kesimpulan dari penelitian ini, penggunaan antihipertensipada pasien hipertensi rawat inap di RS DaerahDr. A. Dadi Tjokrodipo Bandar Lampung sudah rasional.
\end{abstract}

Kata Kunci: Antihipertensi. Hipertensi, Rasionalitas Penggunaan Obat.

\section{PENDAHULUAN}

Salah satu penyakit tidak menular yang saat ini menjadi prioritas dalam dunia kesehatan secara global adalah hipertensi. Berdasarkan rekomendasi Join National Committee dalam The Eighth Report of Join National Committee on Prevention, Detection, Evaluation and Treatment of High Blood Pressure menyatakan bahwa tekanan darah tinggi (hipertensi) merupakan suatu keadaan dimana tekanan darah seseorang $\geq 140 \quad \mathrm{mmHg}$ (sistolik) dan/atau $\geq 90 \mathrm{mmHg}$. Selain sebagai salah satu jenis penyakit tidak menular, Hipertensi juga menjadi faktor risiko utama penyakit kardiovaskuler lainnya[1]. Hipertensi suatu penyakit yang sangat berbahaya, karena tidak ada gejala atau tanda khas sebagai peringatan dini. Kebanyakan orang merasa sehat dan energik walaupun hipertensi[2].
Berdasarkan data dari WHO (World Health Organization), penyakit ini menyerang $22 \%$ penduduk dunia, dan diperkirakan pada tahun 2025 akan ada 1,5 miliar orang yang terkena hipertensi, serta setiap tahunnya 9,4 juta orang meninggal akibat hipertensi dan komplikasinya. Sedangkan di Asia tenggara, angka kejadian hipertensi mencapai $36 \%$. Dari hasil riskesdas yang terbaru tahun 2018, prevalensi kejadian hipertensi sebesar $34.1 \%$, tertinggi di Kalimantan Selatan (44\%), sedangkan terendah di Papua sebesar $(22,2 \%)[3]$. Angka ini meningkat cukup tinggi dibandingkan hasil riskesdas tahun 2013 yang menyampaikan kejadian hipertensi berdasarkan hasil pengukuran tekanan darah pada masyarakat Indonesia berusia 18 tahun ke atas adalah 25.8\%[4].

Prevalensi hipertensi mengalami peningkatan yang signifikan pada 
pasien berusia 60 tahun ke atas. Belakangan ini kita mulai sering mendapati kejadian hipertensi pada usia yang relatif lebih muda di masyarakat kita. Hal ini dapat dilihat dari prevalensi hipertensi di Indonesia pada tahun 2013 pada kelompok usia muda, yaitu kelompok usia 18-24 tahun sebesar 8.7\%, kelompok usia 25-34 tahun sebesar $14.7 \%$ dan pada kelompok usia 35-44 tahun sebesar 24.8\%.Dan dari hasil riset yang terbaru pada tahun 2018 angka ini mengalami peningkatan yang cukup signifikan menjadi $13.2 \%$ pada usia $18-24$ tahun, $20.1 \%$ di usia $25-34$ tahun dan $31.6 \%$ pada kelompok usia 25-44 tahun. Penyebab pasti terjadinya hipertensi sampai saat ini masih belum diketahui. Namun ada beberapa faktor yang menjadi risiko terjadinya hipertensi, seperti jenis kelamin, usia, obesitas, merokok dan kurangnya aktivitas fisik[4].

Penatalaksanaan hipertensi secara garis besar dibagi menjadi dua yaitu farmakologis dan non-farmakologis, dalam kondisi patologis hipertensi memerlukan penanganan atau terapi. Pada terapi non-farmakologi merupakan terapi yang tidak menggunakan obat atau senyawa yang dalam kerjanya mempengaruhi tekanan darah seperti diet, melakukan aktivitas fisik, tidak merokok, dan lain-lain. Pada penatalaksanaan farmakologi hipertensi memiliki beberapa macam golonganobat yang digunakan yaitu ACEI, ARB, CCB, Diuretik, $\beta$-bloker, dan lain-lain.[5]. Pemilihan obat merupakan salah satu faktor yang sangat penting terutama obat hipertensi. Semakin banyak obat yang digunakan, maka perhatian khusus juga semakin diperlukan apakah penggunaan obat tersebut sudah digunakan dengan benar.

Seiring dengan peningkatan kasus hipertensi, maka penggunaan obat yang rasional oleh pasien hipertensi merupakan salah satu elemen penting dalam tercapainya kualitas kesehatan. Rasionalisasi penggunaan obat terdiri dari tepat diagnosis, tepat indikasi penyakit, tepat pemilihan obat, tepat dosis, tepat cara pemberian, tepat interval waktu pemberian, waktu lama pemberian, waspada terhadap efek samping, tepat penilaian kondisi pasien, kepatuhan pasien terhadap pengobatan, dispending, tepat tindak lanjut[6]. Evaluasi penggunaan obat antihipertensi bertujuan untuk menjamin penggunaan obat yang rasional pada pasien hipertensi[7].

Penggunaan obat yang rasional merupakan suatu upaya yang penting dalam rangka pemerataan obat dan keterjangkauan oleh masyarakat serta mengharuskan pasien menerima penggobatan sesuai dengan kebutuhan klinis, dalam dosis yang diperlukan tiap individu dalam kurun waktu tertentu dengan biaya yang paling rendah[8].

\section{METODE PENELITIAN}

Penelitian ini dilakukan menggunakan metode deskriptif dengan pengambilan data secara retrospektif yaitu berdasarkan pada data rekam medik pasien yang terjadi di masa lalu. Data diambil dari rekam medik pasien hipertensi diinstalasi rawat inap RSUD Dr. A. Dadi Tjokrodipo Bandar Lampung yang dicatat dalam rekam medik pasien.

Teknik pengumpulan sampel dilakukan dengan metode Purposive Sampling yaitu dengan mengambil keseluruhan rekam medik yang memenuhi kriteria inklusi sebagai sampel.

\section{Lokasi dan Waktu Penelitian}

Penelitian ini dilakukan di Instalasi Farmasi Puskesmas Rawat Inap Dr. A. Dadi Tjokrodipo Bandar Lampung, yang 
beralamat di Jl. Basuki Rachmat No. 73, Teluk Betung Kota Bandar Lampung.Kota Bandar Lampung pada bulan mei tahun 2020.

\section{Populasi dan Sampel}

Populasi dalam penelitian ini adalah seluruh rekam medik pasien hipertensi diinstalasi rawat inap RSUD Dr. A. Dadi Tjokrodipo Bandar Lampung pada periode tahun 2019. Sampel dari penelitian ini yaitu rekam medik yang diberi informasi tentang nama pasien, jenis kelamin pasien, umur pasien, nama obat, golongan obat dengan dosis yang sesuai dan memenuhi kriteria inklusi.

Sampel adalah objek yang diteliti dan dianggap mewakili seluruh populasi. Sampel dalam penelitian ini adalah sebagian dari seluruh populasi yang dihitung berdasarkan rumus slovin. Setelah dilakukan perhitungan didapatkan sampel 82 dari total populasi 482 rekam medik.

\section{Instrumen dan Pengolahan Data}

Lembar data rekam medik pasien, yaitu berisi nama, usia, jenis kelamin, berat badan, diagnosa hipertensi dan terapi hipertensi.

Analisa data yang dilakukan dalam penelitian ini adalah data rekam medik pasien hipertensi rawat inap di RS Daerah Dr. A .Dadi Tjokrodipo Bandar Lampung dikumpulkan lalu diorganisasikan dan dianalisa untuk melihat kerasionalan penggunaan obat berdasarkan JNC 8 dan Pedoman Pelayanan Kefarmasian Pada Hipertensi KEMENKES 2019.

Pengolahan data dilakukan dengan program komputer Microsoft excel danMicrosoft Word untuk menghitung persentase rasionalitas penggunaan obat pasien hipertensi rawat inap di RS Daerah Dr. A. Dadi Tjokrodipo Bandar Lampung.

\section{HASIL DAN PEMBAHASAN}

Berdasarkan hasil penelitian yang telah dilakukan, peneliti mengambil resep berjumlah 82 yang dianggap telah mewakili dari jumlah keseluruhan populasi, maka didapatkan gambaran karakteristik pasien hipertensi yang meliputi umur dan jenis kelamin. pada gambar berikut :

\section{Umur}

Gambaran karakeristik pasien hipertensi rawat inap berdasarkan umur disajikan pada gambar berikut.

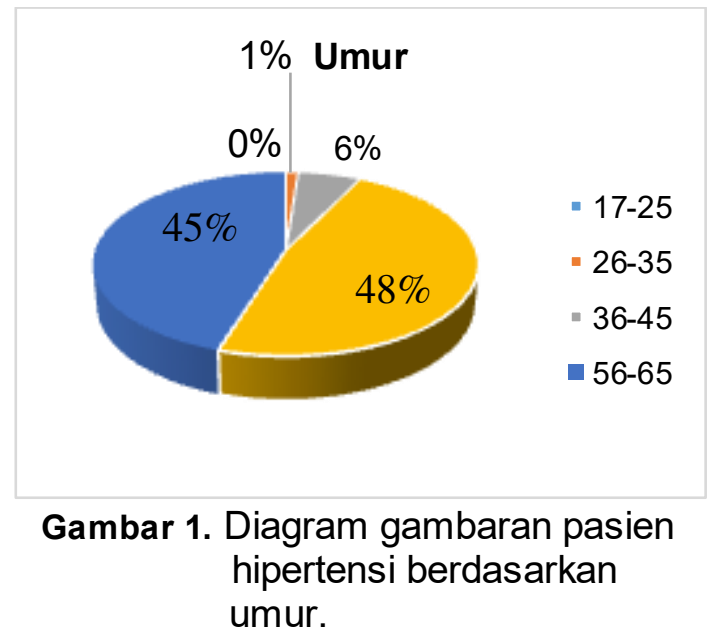

Pada Gambar 1 diatas, jumlah rekam medic pasien hipertensi rawat inap di RS daerah Dr. A. Dadi Tjokrodipo Bandar Lampung pada tahun 2019 yaitu 82 rekam medic pasien hipertensi, diperoleh kelompok umur 17-25 tahun sebanyak 0 penderita dengan persentase $(0 \%)$, kelompok umur 26-35 tahun sebanyak 1 penderita dengan persentase $(1,2 \%)$, kelompok umur $36-$ 45 tahun sebanyak 5 penderita dengan persentase $(6,1 \%)$, kelompok umur $46-$ 55 tahun sebanyak 39 penderita dengan persentase $(47,6 \%)$, dan kelompok 
umur 56-65 tahun sebanyak 37 penderita dengan persentase (45\%).kasus hipertensi berdasarkan usia lebih banyak terjadi pada rentang usia 46 - 55 tahun sebesar $47,6 \%$.

Peningkatan tekanan darah ini disebabkan oleh perubahan struktur pada pembuluh darah besar, sehingga lumen menjadi lebih sempit dan dinding pembuluh darah menjadi lebihkaku. Oleh karena itu darah pada setiap denyut jantung dipaksa melalui pembuluh yang sempit dari pada biasanya dan menyebabkan tekanan darah (27).

\section{Jenis Kelamin}

Gambaran karakeristik pasien hipertensi rawat inap berdasarkan jenis kelamin disajikan pada gambar berikut.

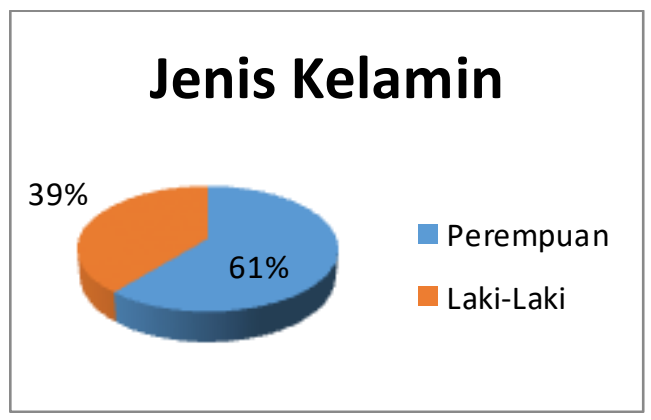

Gambar 2. Diagram gambaran pasien hipertensi berdasarkan jenis kelamin.

Pada Gambar 2 diatas, jumlah rekam medik pasien hipertensi rawat inap Pdi RS daerah Dr. A. Dadi Tjokrodipo Bandar Lampung Pada tahun yaitu 82 rekam medic pasien hipertensi, yang terdiri pasien hipertensi berjenis kelamin laki-laki sebanyak 32 penderita dengan persentase $(39,02 \%)$ dan pada perempuan sebanyak 50 penderita dengan persentase $(60,98 \%)$. Sesuai dengan JNC VII dan VIII bahwa jenis kelamin perempuan lebih beresiko terkena penyakit hipertensi dibandingkan jenis kelamin laki-laki.

\section{Karakteristik Pasien Hipertensi Berdasarkan Tekanan Darah}

Evaluasi pasien hipertensi berdasarkan tekanan darah pada rekam medic rawat inap disajikan pada table berikut.

Tabel 1. Hasil Evaluasi Pasien Hipertensi Berdasarkan Tekanan Darah

\begin{tabular}{|c|c|c|c|c|}
\hline Klasifikasi & $\begin{array}{c}\text { Sistol } \\
(\mathrm{mm} \\
\mathrm{Hg})\end{array}$ & $\begin{array}{c}\text { Diast } \\
\text { ole } \\
(\mathrm{mm} \\
\mathrm{Hg})\end{array}$ & $\begin{array}{c}\text { Juml } \\
\text { ah }\end{array}$ & $\begin{array}{c}\text { Persen } \\
\text { tase }\end{array}$ \\
\hline Normal & $<120$ & $<80$ & 0 & $0 \%$ \\
\hline $\begin{array}{l}\text { Prehipert } \\
\text { ensi }\end{array}$ & $\begin{array}{c}120- \\
139\end{array}$ & $\begin{array}{c}80- \\
89\end{array}$ & 0 & $0 \%$ \\
\hline $\begin{array}{l}\text { Hipertensi } \\
\text { Tahap } 1\end{array}$ & $\begin{array}{c}140- \\
159\end{array}$ & $\begin{array}{c}90- \\
99\end{array}$ & 34 & $41,46 \%$ \\
\hline $\begin{array}{l}\text { Hipertensi } \\
\text { Tahap } 2\end{array}$ & $>160$ & $>100$ & 48 & $58,54 \%$ \\
\hline
\end{tabular}

Hasil evaluasi pada tabel 1 menunjukkan bahwa rekam medic pasien hipertensi di RS Daerah Dr. A. Dadi Tjokrodipo Bandar Lampung paling banyak mengalami hipertensi stadium 2 atau tekanan darah sistolik $\geq 160 \mathrm{mmHg}$ dan tekanan darah diastolik $\geq 100 \mathrm{mmHg}$ yaitu sebanyak 48 pasien sebesar $(58,54 \%)$, sedangkan untuk hipertensi stadium 1 sebanyak 34 pasien sebesar $(41,46 \%)$.

\section{Karakteristik Pasien Hipertensi Berdasarkan Penyakit Penyerta}

Evaluasi pasien hipertensi berdasarkan penyakit penyerta pada rekam medic pasien hipertensi rawat inap disajikan pada tabel berikut. 
Tabel 2. Hasil Evaluasi Pasien Hipertensi Berdasarkan Penyakit Penyerta

\begin{tabular}{|c|l|c|c|}
\hline $\mathrm{N}$ & Jenis & Jumlah & Pesentas \\
$\mathrm{o}$ & $\begin{array}{l}\text { Penyakit } \\
\text { Penyerta }\end{array}$ & $\begin{array}{l}\text { Pasien yang } \\
\text { menderita }\end{array}$ & $\mathrm{e}$ \\
\hline 1 & $\begin{array}{l}\text { Tanpa } \\
\text { penyakit } \\
\text { penyerta }\end{array}$ & 23 & $28,05 \%$ \\
\hline 2 & $\begin{array}{l}\text { Dengan } \\
\text { penyerta }\end{array}$ & Stroke & 27 \\
\cline { 3 - 4 } & & CHF & 9 \\
\cline { 3 - 4 } & CKD & 6 \\
\cline { 3 - 4 } & $\begin{array}{c}\text { Diabetes } \\
\text { Melitus }\end{array}$ & 17 \\
\hline \multicolumn{2}{|c|}{ Jumlah } & 82 & $100 \%$ \\
\hline
\end{tabular}

Hasil evaluasi pada tabel 2 menunjukkan bahwa hasil data yang diperoleh diatas, penyakit penyerta yang paling banyak diderita adalah stroke sebanyak 27 pasien $(32,93 \%)$ diikuti dengan penyakit diabetes mellitus sebanyak 17 pasien (20,73\%), CHF sebanyak 9 pasien $(10,97 \%)$, dan CKD sebanyak 6 pasien $(7,32 \%)$. Sedangkan untuk pasien hipertensi tanpa penyakit penyerta sebanyak 23 pasien (28,05\%). Semakin tinggi tekanan darah pasien kemungkinan timbulnya penyakit lain semakin besar, salah satunya stroke. Karena hipertensi dapat mempercepat pengerasan dinding pembuluh darah arteri dan mengakibatkan penghancuran lemak pada sel otot polos sehingga mempercepat proses aterosklerosis. Hipertensi berperan dalam proses aterosklerosis melalui efek penekanan pada sel endotel/lapisan dalam dinding arteri yang berakibat pembentukan plak pembuluh darah semakin cepat. Akibatnya aliran darah ke aderahdaerah yang dilalui termasuk otak akan berkurang sehingga otak tidak akan mendapat suplai oksigen yang cukup. Kurangnya suplai oksigen inilah yang menyebabkan stroke [10].

\section{Evaluasi Ketepatan Pasien}

Evaluasi ketepatan pasien pada rekam medik pasien hipertensi rawat inap disajikan pada tabel berikut.

Tabel 3. Hasil Evaluasi Ketepatan Pasien

\begin{tabular}{|l|l|l|}
\hline $\begin{array}{l}\text { Ketepatan } \\
\text { pasien }\end{array}$ & $\begin{array}{l}\text { Jumlah } \\
\text { pasien }\end{array}$ & $\begin{array}{l}\text { Persentase } \\
(\%)\end{array}$ \\
\hline $\begin{array}{l}\text { Tepat } \\
\text { pasien }\end{array}$ & 81 & $98,8 \%$ \\
\hline $\begin{array}{l}\text { Tidak tepat } \\
\text { pasien }\end{array}$ & 1 & $1,2 \%$ \\
\hline Total & 82 & $100 \%$ \\
\hline
\end{tabular}

Dari hasil evaluasi pada Tabel 3 menunjukkan bahwa diperoleh penggunaan obat antihipertensi berdasarkan tepat pasien sebanyak 81 pasien yaitu $99,8 \%$ tepat pasien dan sebanyak 1 pasien $(1,2 \%)$ tidak tepat. Dikatakan tepat karena dari semua obat yang diberikan pada pasien hipertensi sesuai dengan kondisi patologi dan fisiologi pasien, serta tidak adanya alergi dan tidak menimbulkan kontraindikasi pada pasien [11], sedangkan dikatakan tidak tepat pasien karena menimbulkan kontraindikasi. Hasil ini berbeda dengan penelitian sebelumnya di RSUP Prof. Dr. R. D. Kandou Manado Periode Januari-Juni 2014 terhadap 39 data rekam medik pasien hipertensi diperoleh nilai penggunaan obat berdasarkan tepat pasien bernilai $100 \%$ tepat [12].

\section{Evaluasi Tepat Indikasi}

Evaluasi tepat indikasi pada rekam medic pasien hipertensi rawat inap disajikan pada tabel berikut.

Tabel 4.Hasil Evaluasi Tepat Indikasi

\begin{tabular}{|c|c|c|}
\hline $\begin{array}{c}\text { Ketepatan } \\
\text { indikasi }\end{array}$ & Jumlah pasien & $\begin{array}{c}\text { Persentase } \\
(\%)\end{array}$ \\
\hline Tepat & 82 & $100 \%$ \\
\hline
\end{tabular}




\begin{tabular}{|c|c|c|}
\hline indikasi & & \\
\hline $\begin{array}{c}\text { Tidak tepat } \\
\text { indikasi }\end{array}$ & 0 & 0 \\
\hline Total & 82 & $100 \%$ \\
\hline
\end{tabular}

Dari hasil evaluasi pada Tabel 4 menunjukkan diperoleh bahwa penggunaan obat antihipertensi berdasarkan tepat indikasi sebanyak 82 pasien yaitu $100 \%$ tepat, karena obat antihipertensi ACEI, ARB, CCB, Diuretik, dan $\beta$-bloker diberikan kepada pasien dengan diagnosis hipertensi tahap 1, tahap 2, ataupun hipertensi dengan komplikasi [13]. Pada penelitian sebelumnya juga di RSUP Prof. Dr. R. D. Kandou Manado Periode JanuariJuni 2014 terhadap 39 data rekam medik pasien hipertensi diperoleh nilai penggunaan obat berdasarkan tepat indikasi sebanyak $100 \%$ tepat. [12].

\section{Evaluasi Tepat Obat}

Evaluasi tepat obat pada rekam medik pasien hipertensi rawat inap disajikan pada tabel berikut.

Tabel 5.Hasil Evaluasi Tepat Obat

\begin{tabular}{|c|c|c|}
\hline $\begin{array}{c}\text { Ketepatan } \\
\text { obat }\end{array}$ & $\begin{array}{c}\text { Jumlah pasien } \\
\text { Persentase } \\
(\%)\end{array}$ \\
\hline $\begin{array}{c}\text { Tepat obat } \\
\text { obat }\end{array}$ & 61 & $25,6 \%$ \\
\hline Tidak tepat & 82 & $100 \%$ \\
\hline $\begin{array}{c}\text { Ketepatan } \\
\text { obat }\end{array}$ & Jumlah pasien & $\begin{array}{c}\text { Persentase } \\
(\%)\end{array}$ \\
\hline
\end{tabular}

Dari hasil evaluasi pada Tabel 5 menunjukkan diperoleh bahwa penggunaan obat antihipertensi berdasarkan tepat obat sebanyak 61 pasien $(74,4 \%)$ tepat obat karena obat hipertensi yang diberikan sudah sesuai standar yang digunakan yaitu JNC VIII dan sebanyak 21 pasien $(25,6 \%)$ tidak tepat obat karena obat hipertensi yang diberikan tidak sesuai dengan standar yang digunakan. Berdasarkan data pengobatan yang diperoleh, terdapat pasien hipertensi dengan penggunaan tunggal maupun kombinasi obat yang tidak sesuai. Selain itu terdapat pemberian obat antihipertensi yang tidak tepat dimana pasien hipertensi dengan tahap 2 menerima terapi satu macam obat [13].

\section{Evaluasi Tepat Dosis}

Evaluasi tepat dosis pada rekam medik pasien hipertensi rawat inap disajikan pada tabel berikut.

Tabel 6.Hasil Evaluasi Tepat Dosis

\begin{tabular}{|c|c|c|}
\hline $\begin{array}{c}\text { Ketepatan } \\
\text { dosis }\end{array}$ & $\begin{array}{c}\text { Jumlah pasien } \\
\text { Persentase } \\
(\%)\end{array}$ \\
\hline $\begin{array}{c}\text { Tepat dosis } \\
\text { dosis }\end{array}$ & 82 & $100 \%$ \\
\hline Total & 82 & 0 \\
\hline
\end{tabular}

Dari hasil evaluasi pada Tabel 6 menunjukkan diperoleh bahwa penggunaan obat antihipertensi berdasarkan tepat dosis sebanyak 82 pasien $100 \%$ tepat dosis, karena dosis obat antihipertensi yang diberikan sudah sesuai dengan range terapi obat antihipertensi berdasarkan Guidelines JNC VIII [13]. Pemberian dosis yangsesuai dengan dosis standar sangatlah penting untuk keberhasilan terapi pasien hipertensi. Apabila dosis yang diberikan kurang obat tidak mampu menghasilkan efek terapi yang diinginkan karena obat tersebut berada dalam rentang subterapeutik. Dosis berlebih mengakibatkan meningkatnya resiko efek samping dan timbulnya ketoksikan. Oleh karena itu, dosis yang tepat mewujudkan keberhasilan terapi pada pasien [9]. Hasil ini berbeda dengan penelitian yang dilakukan sebelumnya di RSUP Prof. Dr. R. D. 
Kandou Manado Periode Januari-Juni 2014 dengan sampel 39 data rekam medik pasien hipertensi diperoleh ketepatan dosis sebanyak $25(64,10 \%)$ tepat dan sebanyak $14(35,90 \%)$ tidak tepat. [12].

\section{SIMPULAN DAN SARAN}

\section{Simpulan}

Berdasarkan hasil dan pembahasan dari penelitian mengenai Rasionalitas Penggunaan Obat Antihipertensi Rawat Inap di RS Daerah Dr. A. Dadi Tjokrodipo Bandar Lampung, dapat disimpulkan sebagai berikut:

1. Karakteristik pada pasien hipertensi di RSUD Dr. A. Dadi Tjokrodipo Bandar Lampung Tahun 2019, diperoleh 50 pasien perempuan sebesar $60,98 \%$ dan 42 pasien lakilaki sebesar $39,02 \%$. Berdasarkan usia diperoleh usia 17-25 tahun sebanyak 0 pasien $(0 \%)$, usia $26-35$ tahun sebanyak 1 pasien $(1,2 \%)$, usia 36-45 tahun sebanyak 5 pasien $(6,1 \%)$, usia $46-55$ tahun sebanyak 39 pasien $(47,6 \%)$, dan usia $56-65$ tahun sebanyak 37 pasien (45,1\%).

2. Karakteristik pasien berdasarkan tekanan darah diperoleh paling banyak mengalami hipertensi stadium 2 atau tekanan darah sistolik $\geq 160 \mathrm{mmHg}$ dan tekanan darah diastolik $\geq 100 \mathrm{mmHg}$ yaitu sebanyak 48 pasien sebesar $(58,54 \%)$, sedangkan untuk hipertensi stadium 1 sebanyak 34 pasien sebesar $(41,46 \%)$.

3. Karakteristik pasien berdasarkan hipertensi dengan penyakit penyerta yaitu hasil data yang diperoleh diatas, penyakit penyerta yang paling banyak diderita adalah stroke sebanyak 27 pasien $(32,93 \%)$ diikuti dengan penyakit diabetes mellitus sebanyak 17 pasien $(20,73 \%)$, CHF sebanyak 9 pasien (10,97\%), dan CKD sebanyak 6 pasien $(7,32 \%)$. Sedangkan untuk pasien hipertensi tanpa penyakit penyerta sebanyak 23 pasien $(28,05 \%)$.

4. Pola penggunaan antihipertensi untuk pasien hipertensi di RSUD Dr. A. Dadi Tjokrodipo tahun 2019 diperoleh antihipertensi yang paling banyak digunakan yaitu amlodipine golongan CCB sebanyak 54 pasien sebesar (45\%).

5. Rasionalitas penggunaan antihipertensi pada pasien hipertensi di RSUD Dr. A. Dadi Tjokrodipo Bandar Lampung tahun 2019 diperoleh berdasarkan ketepatan pasien sebesar $99 \%$, ketepatan indikasi sebesar $(98,8 \%$ tepat indikasi\%, ketepatan obat $(74,4 \%)$, dan ketepatan dosis sebesar $100 \%$.

\section{Saran}

Berdasarkan kesimpulan diatas, peneliti memberi saran sebagai berikut:

1. Bagi Instansi Rumah Sakit

a. Meningkatkan pemantauan terhadap kelengkapan rekam medik pasien, penulisan yang lebih jelas sehingga mempermudah pemantauan kondisi pasien.

b. Meningkatkan penyimpanan arsip rekam medik sehingga mempermudah dalam pencarian dan meminimalisir kerusakan dan kehilangan dalam pengarsipannya.

c. Meningkatkan pelayanan medis dengan menyediakan standar pelayanan medis pada pasien hipertensi.

2. Bagi Peneliti Selanjutnya

Perlu dilakukan penelitian lanjutan mengenai kepatuhan pasien dalam penggunaan obat antihipertensi. Hal ini bertujuan 
untuk meningkatkan kualitas kesehatan pasien dimana dengan meningkatkan kepatuhan pasien dalam penggunaan obat antihipertensi maka dapat menurunkan resiko terjadinya penyakit komplikasi ataupun kerusakan organ penting lainnya yang disebabkan oleh hipertensi.

\section{UCAPAN TERIMAKASIH}

Terimakasih kepada seluruh pihak Universitas Tulang Bawang Lampung dan Puskesmas Rawat Inap Sukabumi Bandar Lampung yang telah membantu dalam menyelesaikan penelitian.

\section{DAFTAR PUSTAKA}

[1].Ansar J, Dwinata I MA. Determinan Kejadian Hipertensi Pada Pengunjung Posbindu Di Wilayah Kerja Puskesmas Ballaparang Kota Makassar. J Nas IImu Kesehat. 2019.

[2].Kementrian Kesehatan Republik Indonesia (Kemenkes RI). Hipertensi penyebab kematian nomor tiga. Pus Komun Publik, Sekr Jenderal Kementeri Kesehatan. 2010.

[3].Riset Kesehatan Dasar (RISKESDAS). laporan Nasional. Badan Penelitian dan Pengembangan Kesehatan Riset. 2018.

[4].Tirtasari S, Kodim N. Prevalensi dan karakteristik hipertensi pada usia dewasa muda di Indonesia. Tarumanagara Med J. 2019.
[5].Triyanto E. Pelayanan Keperawatan bagi penderita Hipertensi Secara Terpadu. J Kesehat Med SANTIKA. 2014.

[6].Kemenkes RI. Modul Penggunaan Obat Rasional. kemenkes RI. 2011.

[7].Erene Nanda Lyswanti Suyono. Studi Pengguna Obat Antihipertensi Pada Penderita Hipertens Rawat Inap. 2005;113.

[8].WHO. Adherence to long-term therapies: Evidence for action. World Health Organization. Eur J Cardiovasc Nurs. 2012.

[9].Pedoman Teknis dan Tata Laksana Penyakit Hipertensi, Direktorat Pengendalian Penyakit Tidak Menular Direktorat Jendral PP \& PL Departemen Kesehatan RI Tahun 2010.

[10].American Heart Association. classes oh heart failure. 2011.

[11].Farmakope Indonesia Edisi III. Departemen Kesehatan Republik Indonesia, Jakarta. Tahun 1979.

[12].Sumawa PMR, Wullur AC, Yamlean PVY. Evaluasi Kerasionalan Penggunaan Obat Antihipertensi Pada Pasien Hipertensi Rawat Inap Di Rsup Prof. Dr. R. D. Kandou Manado Periode Januari-Juni 2014. PHARMACONJurnal IIm Farm UNSRAT. 2015.

[13].Muhadi. JNC 8: Evidence-based Guideline Penanganan Pasien Hipertensi Dewasa. Cermin Dunia Kedokt. 2014. 